\title{
Religion in education policy in South Africa: a challenge of change
}

\author{
Albertina Maitumeleng Ntho-Ntho and Jan Nieuwenhuis* \\ Department of Education Management and Policy Studies, University of Pretoria, South Africa \\ ${ }^{\star}$ Corresponding author. Email: jan.nieuwenhuis@up.ac.za
}

Since 1995, the National Department of Education has developed a number of policies to give effect to the proposed transformation outlined in White Paper 1 (Notice 196 of 1995) and in subsequent legislation. A range of Acts and policies were introduced, many of them dealing with how religion should be dealt with in schools and it culminated in the promulgation of the National Policy on Religion and Education (2003). In all these policies the role of the school and, in particular, of the school principal has been foregrounded as important for effective implementation of policies. This article is based on research conducted to determine how school principals dealt with religion and the implementation of the religion and education policy. This study found that school principals often ignore the policy and maintain the status quo. When faced with conflict of religious interests, they partially sub-contract into the policy. The study also found that past experiences with religion in education, either as students or educators, had a major impact on how principals perceive the role of religion in schools and how they dealt with it.

Keywords: religion education; religion-in-education policy; religious education; religious observances

\section{Introduction}

It has been the desire of the ANC government to develop a unity of purpose and spirit that cherishes and celebrates the diverse nature of the South African population in terms of culture, language and religion. The aim behind such desire has been mainly to transform the existing inequalities that are deep-rooted in South African educational history and religion in particular ever since it came to power, after 1994. In order to facilitate this desire, a whole plethora of legislation and policies were developed. Amongst the developments entailed in these laws and policies, to mention few but mostly those around which this article revolves were (1) religious rights and freedoms guaranteed to all South Africans and (2) the establishment of democratic structures vested with powers to govern while 
the school principal sees to the management of the school. In terms of this legislation, one of the functions of the governing body of the school is to develop and adopt the religion policy of the school which is put into practice by the school principal. It is in this important process where the school principal is expected to play the mediating role and resolve the possible conflicts that may erupt out of different religious interests.

It would be imperative, therefore, to mention that due to the potential or actual conflict arising from his/her role, the school principal is an influential member of the school governing body (SGB) on whose advice and guidance other members depend. As such, one would be influential in determining the nature of the school's religion policy from the Department of Education. On the other hand, the principal implements policy determined by the SGB or from the department according to his/her interpretation and that of the SGB and/or Department. A principal can, therefore, be perceived by other stakeholders as the source or cause of the conflict arising from religion policy implementation. The irony is that it is the very conflict that principals are supposed to mediate.

Based on the following assumptions: (1) their position as school managers and leaders, (2) the leadership and management theories they studied during teacher training and (3) the subsequent professional development programmes they received from Departments of Education, we were convinced that school principals were sufficiently equipped with the ability to implement religion policy according to the rules determined by the SGB. This article, therefore, attempts to answer the research question that follows: 'How did school principals deal with implementation of the National Policy on Religion and Education in schools?' In doing so, relevant legislation and policies were reviewed in order to determine the type of citizen government wants to develop through education and to understand the directives outlined in support of schools in implementing such policies.

\section{The rationale for religion in education}

Although South Africa has never completely denied religious freedom and diversity, the wrongs perpetrated in this regard during the apartheid era could thus be described as a denial of equal freedom and treatment to the followers of religions other than Christianity. Nonetheless, this suggested the existence of inequalities that are deep-rooted in South African education history with regard to religion in particular. One way in which religious public education institutions have discriminated against learners in terms of religion was to subject learners to religious observances without their or their parents' consent. Another was to include confessional or sectarian forms of religious instruction in public school curricula, thereby compelling learners to accept and conform to specific religious beliefs or practices (DoE 2003). 
The post-1994 government decided that it was necessary for all religions to be treated equally, also in education, and that learners should be taught to respect religious diversity in their interaction with others in order to promote greater tolerance and understanding. These policies could not and might have not been developed in a lacuna; they were framed within the requirements of the Constitution, existing legislation and with due attention to other policies or expectations of the Department of Education and other interested groups.

\section{The South African Constitution (Act 108 of 1996)}

The Constitution of the Republic of South Africa, Act 108 of 1996, guarantees the right to religious freedom and religious diversity. It commits the State to the protection and promotion of individuals' and groups' religious rights, thereby affording people the freedom to follow their own religious orientations while simultaneously adhering to legislated constitutional principles (RSA, Act 108 of 1996). More specifically, the Constitution ensures freedom of conscience, religion, belief and opinion for every South African citizen (section, 15(1)). Further provision is made for religious observances to be conducted at State or State-aided institutions provided that (a) they follow the rules laid down by the appropriate public authorities, (b) they are conducted on an equitable basis and (c) attendance at such observances is free and voluntary (Section 15[2]). In stipulating these provisos, the State aims to balance individual rights with group rights.

The government is, therefore, bound to establish a society based on democracy and equal citizenship, and to ensure that the fundamental rights and freedoms of all South Africans are protected. Protecting people's right to belong to any religion without fear of being persecuted or discriminated against (Masondo 2011) is one way of achieving this purpose.

The religious freedom guaranteed by the Constitution is reaffirmed in the South African Schools Act (Act 84 of 1996) and is further refined in specific policies and regulations. The same Act, however, also mandates the establishment of democratically elected school governing bodies, indicating the roles, functions and responsibilities they are to perform. These include drafting the code of ethics, the mission of the school and policies on language and religion in education.

\section{The South African Schools Act (Act 84 of 1996)}

Concurring with the Constitution, Section 7 of the South African Schools Act (Act 84 of 1996) clearly stipulates that

subject to the Constitution and any applicable provincial law, religious observances may be conducted at a public school under rules issued by the 
governing body if such observances are conducted on an equitable basis and attendance at them by learners and members of staff is free and voluntary.

Insisting that public schools are institutions with a mandate to serve society as a whole, the South African government is determined to equip learners with knowledge of religion, morality, values and diversity in this regard. Schools are allowed to use religion education to reinforce and/or reaffirm constitutional values like diversity, tolerance, respect, justice, compassion and commitment in young South Africans. Creating opportunities for learners to examine, critically and creatively, the moral codes embedded in all religions, their own and others through religion education (Amin et al. 1998 ) is a step towards the realisation of these goals.

Research evidence suggest that religion education, when given its rightful place in the education system, creates opportunities for the imparting of moral values in the teaching of and learning of religions and other value systems (Mkhatshwa 1998; DoE 2003; Abdool and Drinkwater 2005; Ter Avest and Bakker 2005; Dreyer 2007; Miedema and Bertram-Troost 2008; Marashe, Ndamba, and Chireshe 2009; Sasson and Sasson 2009). It is therefore important to mention that, with current concerns about the general decline in moral standards, the high rate of crime, and the apparent lack of respect for human life in this country, the State seeks to realise the benefits of religion as an important human activity, something which all learners should know about if they are to be holistically educated. The State also seeks to understand pressures brought about by the dissolution of apartheid barriers namely classrooms that are increasingly becoming spaces of linguistic, cultural and religious diversity. These factors, therefore, bind schools to mediate between old and new systems, creating a social, intellectual, emotional, behavioural, organisational and structural environment that reflects a sense of acceptance, security and respect for people with different values, cultural backgrounds and religious traditions.

\section{The national policy on religion and education}

It is for the above aim that in 2003, the National Policy on Religion and Education was released. This policy was meant to transform the single-faith approach to religious education - Christian Religious Education (education based on biblical teachings aimed at instilling in learners Christian beliefs and values) into a multi-tradition approach to religion education - education about diverse religions for a diverse society. Although the journey of the policy development was realised in 1994, soon after the democratic elections, there has been an extensive debate over the possible model that could be used to restructure the relationship between religion and education.

Finally, the decision on a 'co-operative model' was reached and the National Policy on Religion and Education emerged as a consensus 
document about the relationship between religion and education (DoE 2003). In terms of this 'co-operative model' the South African approach to religion and education recognises not only the 'separate spheres for religion and the State' under the Constitution, but also the 'scope for interaction between the two' (Dreyer 2007; Mawdsley, Cumming, and De Waal 2008; Van Der Walt 2010). According to the State, its co-operative model was a reaction against both the apartheid 'theocratic model', which tried to impose religion in public institutions, and the USA 'separationist model' that completely divorces the religious sphere of society from the secular one (Dreyer 2007; Mawdsley, Cumming, and De Waal 2008; Van Der Walt 2010).

Instead of converting learners from one religion to the other, religion education is aimed at providing learners with the opportunity to develop a deeper sense of self-realisation and a broader civil tolerance of others and to balance the familiar and the foreign in ways that give them new insights into both (DoE 2003; Smock 2005). Schools therefore ought to explain what religions are about by indicating clearly - in ways that increase understanding, build respect for diversity, value spirituality, and clarify the religious and non-religious sources of moral values - which educational goals and objectives are being pursued (DoE 2003; Abdool and Drinkwater 2005). In doing so, schools would be providing learners with the opportunity to question the validity of values and morals other than their own, in a changing or non-religious society or world view (Roux 2006).

Just as the right of learners to be at school must be ensured and protected, so must their right to have their religious views recognised, appreciated and respected (Minister's foreword 2003). Instead of linking the content to the values and morals of a particular religious society which represents the teacher's own religious orientation, religion education in South Africa is aimed at the presentation and discussion of a world of religious diversity (Roux 2006).

Researchers like Jackson (2005) support this initiative, indicating that religion education communicates the importance of values that 'compel transformation', values like democracy, social justice and equity, non-racism and non-sexism, Ubuntu (human dignity), an open society, the rule of law, respect and reconciliation (DoE 2001). Moreover, according to Jackson (2005), it is important in religion education to combat any form of discrimination and intolerance based on religion or belief and to prevent violations of the human right to freedom of religion or belief. Given principals' roles, the execution of this duty has not been easy for them.

\section{Trends in religion policy discourse}

It would, however, be wrong to limit religion to these constitutional guarantees. It was not until 2003 that the government released the religion policy although the journey of its development was realised in 1994, soon after the 
democratic elections. In the opinion of many parents, the government school system is hostile to their religious convictions (Dreyer 2007). An increasing number of court and legislative conflicts between governments and parents over education show this plainly (De Groff 2009). Key areas of conflict hinge on issues such as whether or not parents may exempt children from certain classes with objectionable content, whether citizens or governments may allocate tax monies to the support of private religious schools, to what extent parents may influence content selection in classes, whether prayer is permitted in schools or at school activities, to what extent may religious student groups exist, and many others (Donnelly 2011).

The case of Mfolo and others $v$ Minister of Education, Bophuthatswana 1994 (1) BCLR 136 (B), where a learner had to sign a code of conduct which included an agreement that any learner who becomes pregnant would have to leave school since there are some religions that prohibit 'sex before marriage', reiterates the point made above. By so doing, the school violated Sections 9(3) that prohibits unfair discrimination on the grounds of, among others, religion and 29 of the Constitution (Act 108 of 1996) that guarantees everyone the right to education. By so doing, the Constitution enforces respect for and protection of the most basic constitutional values of equality and human dignity.

In the case, Christian Education SA v Ministry of Education 2000 (4) SA 757 (CC); 2000 (10) BCLR 1051 (CESA), an organisation of concerned Christian parents challenged the constitutionality of Section 10 of the South African Schools Act (84 of 1996), which prohibits corporal punishment at school. According to Christian Education South Africa (CESA), 'corporal punishment' forms part of a system of 'discipline' based on the Christian faith and scriptures. The organisation claimed, moreover, that corporal punishment, as administered at its schools, is part of the common culture of such schools, a culture which is protected by certain provisions of the Constitution. In turning down the application, the court pointed out that the biblical authority on which the applicants relied suggested that only parents of children (and not school officials in loco parentis) were entitled to administer corporal punishment. This judgment indicates that, even though the Constitution guarantees the right to freedom of religion and expression, religion is still subordinate to the authority of the State.

\section{Research methodology}

The research seeks to explore and understand the meanings principals construct in their personal encounters with legislation binding them to the implementation of new religion policies but also to uncover the nature of such situations, processes, relationships, systems or people (Leedy and Ormrod 2005). It was also our intention to gain insight into social, emotional and experiential phenomena, especially in the challenging and 
controversial context that is religion in education and thus enable us to provide an in-depth description of human experience (Lichtman 2010) through the eyes of research participants. The research was, therefore, based on a qualitative approach in which a phenomenological research design was used.

The use of a phenomenological research design enabled the researchers to examine principals' experiences about religion that are based on their personal views rather than as the views of spokespersons for specific schools. We were therefore able to probe into what principals like or dislike about the religion-in-education policy.

With the use of phenomenological research design, we first tried to understand the specific religious orientations of principals and to determine how these orientations were shaped while they were learners and young educators. Then, we determined how they approached the implementation of religion in education policy in particular. We assumed that data collected on the first aspect - their religious orientations - would explain their allegiance to a specific interest group when it came to policy implementation, and that the second aspect - their policy implementation approach - would help us understand the challenges in reconciling their own position with the positions of others. We were thus able to explore principals' experiences with further absorption and interpretation of collected data based on researchers' theoretical and personal knowledge (Ajjawi and Higgs 2007). At first, we described the life stories of principals following this with the identification of general themes on the essence of the phenomenon. The aim of these attempts was to go beyond surface expressions or explicit meanings so as to access the implicit dimensions and intuitions of principals' experiences (Finlay 2009). In so doing, we entered into the so-called 'life worlds' of participating principals, uncovering the meaning structures of their lived experiences. We then described these, thereby gaining a deeper understanding of the nature and meaning of everyday mundane experiences of school principals who mediated or sub-contracted into policy implementation in schools (Cilesiz 2008). Interpreting such experiences meant honouring principals' words, meanings and voices (Sharma-Brymer and Fox 2008). Understanding the very descriptions and experiences implied an understanding of their particular private and public spheres as well as their private religious lives which might possibly lie unexplored but ready for public understanding (Rogers 1993).

Mature principals who have been exposed to the apartheid system where schools were divided along racial lines, who were also post-graduate students (i.e. students enrolled in BEd (Hons), Master's and/or Doctoral programmes) at the University of Pretoria were interviewed. Informing this choice was our assumption that principals who were in the field of education management and leadership with at least ten years of experience as educators and/or principals in the new South Africa would have acquired the appropriate knowledge, skills, values and attitudes to be able to 
successfully mediate and implement policies such as those on religion in schools.

We obtained ethical clearance from the Faculty of Education to involve these principals/post-graduate students in the study whether they were spokespersons of the Department or schools. Once permission had been granted, we had to extend invitations to them through direct and/or e-mail contact. The invitations were directed at school principals who were willing to participate regardless of gender, province, historic origin and type of schools (secondary or primary) in which they worked.

First, principals' narratives were transcribed shortly after they were collected. Individual transcriptions were analysed in terms of the initially identified categories. These included principals' past and present positive and negative experiences of different religion policies as well as the management strategies they employed in dealing with these policies in schools.

Secondly, using the WEFT Qualitative Analysis programme, we coded the data in terms of these categories, identifying what Schütze called indexical statements that refer to 'who did what, where, when and why', as well as non-indexical material which go beyond events and express values, judgements and any other form of generalised 'life wisdom'. During this process, we paid special attention to those descriptive statements that explained how events were 'lived', 'felt' and 'narrated', the values and opinions attached to them, as well as to the usual and the ordinary. Argumentative statements were also attended to in order to legitimise what was not taken for granted in the stories and reflections in terms of general theories and concepts about the events.

We collected data over a period of 4-5 months using narrative inquiry to examine principals' experiences about religion policies. We were able to go beyond probing what they like or dislike about the religion-in-education policy. Being quite aware that we could influence the interviews to a certain extent, thereby making all interpretations subjective, we kept on searching for a deeper understanding and interpretation by asking multiple but related questions at various stages during the interviews (e.g. 'Is this what you said, did you say this, what did you mean by this ...?').

The raw data (tape recorded interviews), interview transcripts, interview guides, list of participants and their profiles, as well as our field notes were audited throughout the study period to validate their accuracy and authenticity. In addition to this, we sent transcriptions to participants, asking them to correct errors of fact. This served to ensure that we represented them and their ideas accurately (Mertler 2006). Finally, the study went through the programme called 'turn-it-in' as per the university's requirements to ensure its originality. 


\section{Findings}

From the data presented, a review of participating principals' past experiences of religion in schools, particularly prior to 1994, revealed the important role that religion played in schools as well as the influence - positive as well as negative - which this had on their own lives. They found religious teachings, regardless of religious affiliation, to have inculcated in them valuable life principles, like respecting and loving one another. These principles have, according to them, become the norm for acceptable social behaviour - avoiding murder, adultery and theft. It is for these reasons that they regard religion to be their lives' compass. One of the participants was adamant that religious instruction was

Morally good because it showed us the way, love for people, respect for other people, you know, this I believe is the correct way of doing things; this is the correct way of living. So, that is the reason that I say, what I learnt then, it is still part of me.

As custodians of religious and educational knowledge principals were highly respected and honoured, not only in the schools of which they were in charge but also in the communities where they lived. Because of this their right to make decisions on religious matters in schools, including decisions on morning devotions, were seldom if ever questioned, hence stakeholder groupings had no say in this regard. School days typically commenced with a prayer, hymn singing and scripture reading which were compulsory for all learners and staff, regardless of their religious beliefs. Moreover, only those parents who themselves were ministers, pastors or religious leaders were invited to offer sermons to learners and staff. This was echoed by the other participant that 'morning assemblies in those years were a matter of must: every morning they had to assemble and one member of staff would read a text from the Bible, explain it and they would conclude with a prayer'.

According to participating principals, religion was fundamental to their training as educators. At this stage of their lives, Christian religious education became more communal in the sense that, as learners, they had to demonstrate understanding and commitment by transmitting acquired Christian values and norms to the next generation through Sunday school teaching and by ensuring the continuation of the Christian way of life through participation in or establishment of Student Christian Movements.

As a follower of Jesus, whom he regarded as a role model for teachers, one participant said, I became actively involved in church services, something that led to my graduation as a Sunday school teacher for junior children. My role as the Sunday school teacher went on even when I went to university. 
As young educators, participating principals were aware of religious changes that came along with the Constitution after 1994. Some of the changes they mentioned were that, although morning assemblies remained the responsibility of the principal they were no longer compulsory but free and voluntary; that no learners may be refused admission to a school, and that no educator may be refused appointment on religious grounds. It is because of this clause that two of the participating principals who grew up in the Hindu faith were appointed to predominantly white, Christianoriented schools regardless of the fact that they were Indians. One of the participants pointed out that '... nothing changed in terms of religious observances at the assembly apart from the fact that staff members and learners who were non-religious were not forced to attend assemblies: they were free to excuse themselves'.

The data established that participants were aware of the release of the new religion policy in 2003 but that most of them did not welcome it with open hands. Some claimed that it was not applicable to their single-culture schools '... school community knows what it wants for its children thus enforcing religions that were not their preference on their children was not a proper way of doing things and provoked conflict', while others were unsure of the way in which they should approach it in their multi-cultural/ multi-religion schools. "What challenged me most, the other participant said, was the fact that 23 Muslim learners would ask to be excused to go to mosque every Friday at 12:00'.

Indications from the data were that when the policy was released for implementation, principals received little guidance from education departments on how to go about implementing it even though they attended workshops that informed them of the right to freedom of religion and expression to which every person was entitled. 'We attended different courses where we were told that "everyone has the right to freedom of religion", but practically, when we come to the school, we would want learners to practice Christianity', one of the participants claimed. It may well be that the workshops were deficient in 'unpacking' the policy and that this could be one of the reasons why some participants felt that the policy was just brought to schools without any explanation. This was evident from another participant's claim that '... the policies just come and there were no people to unpack them'. This could also be why participants, in their struggle to interpret and understand their role as policy implementers relied on their past experiences and remained promoters of Christianity instead of protecting human rights and promoting the values stipulated in the Constitution and SASA.

\section{Conclusion}

It is evident that all religions instil moral values in their followers. However, participating principals regarded their school days as a frame of 
reference or baseline in terms of guiding current and future generations to come, ascribing learner and educator ill-discipline today to the absence of Christian religious education in the school curriculum. According to them, religious education was the source of moral values such as respect, discipline; norms such as love, respect and care for one another. They therefore felt the need for learners of today to have religious - mostly Christian education as part of the school curriculum. For these reasons, they referred more to their past religious experiences than to their current experiences with the implementation of the new religion policy in schools. In doing so, they ignore the policy in preference of maintaining the status quo.

When faced with conflicts related to religious issues, school principals partially sub-contracted into the policy. They did not seem to consider mediation as a possible leadership strategy for conflict resolution in the existing religious context of schools although they had received training on conflict resolution strategies as part of their post-graduate studies. It could be inferred, therefore, that (a) principals have received training but that did not make them skilled in the use of mediation, or (b) they lack the requisite values and attitudes particular to mediation processes. When faced with conflict it was easier to sub-contract into the wishes of a particular stakeholder grouping than engaging in a drawn-out process of mediation. This suggests the need for teacher training programmes to include training on the mediation of conflict, particularly in an era where unionism is growing as an important force in education in South Africa.

\section{Notes on contributors}

Albertina Maitumeleng Ntho-Ntho is a post-doctoral research fellow in the Faculty of Education, University of Pretoria, South Africa. Email: Maitumeleng. Nthontho@up.ac.za

Jan Nieuwenhuis is a professor and Head of the Department of Humanities Education, Faculty of Education, University of Pretoria, South Africa. Email: jan.nieuwenhuis@up.ac.za

\section{References}

Abdool, A. D., and M. Drinkwater. 2005. "Guidelines to Create Positive Classroom Climate for Religion Education: An Empathetic Approach.” Scriptura 89: 363372.

Ajjawi, R., and J. Higgs. 2007. "Using Hermeneutic Phenomenology to Investigate how Experienced Practitioners Learn to Communicate Clinical Reasoning." The Qualitative Report 12 (4): 612-638.

Amin, M. S., S. Jankelson-Groll, N. Mndende, and A. B. Omar. 1998. Rainbow Religions. Multi-faith Religion Education. A Resource Book for Teachers and Learners. Cape Town: Maskew Miller Longman (Pty). 
Cilesiz, S. 2008. "Educational Computer Use in Leisure Contexts: A Phenomenological Study of Adolescents' Experiences at Internet Cafes." American Educational Research Journal 46 (1): 232-274.

De Groff, E. A. 2009. "Parental Rights and Public School Curricula: Revisiting Mozert after 20 Years." Journal of Law \& Education 38: 83-134.

Donnelly, M. P. 2011. "Religious Freedom in Education. Real pluralism and real democracy require real choices for parents." International Journal of Religious Freedom 4 (2): 61-75.

Dreyer, J. S. 2007. "The National Policy on Religion and Education in South Africa: Reflections from a Public Practical Theology." Practical Theology in South Africa 22 (2): 40-50.

Finlay, L. 2009. "Debating Phenomenological Research Methods." Phenomenology and Practice 3 (1): 6-25.

Jackson, R. 2005. "How Far can Religion Education Contribute to Multi-cultural/ Inter-cultural Education?" Scriptura 89: 235-246.

Leedy, P. D., and J. E. Ormrod. 2005. Practical Research: Planning and Design. 8th ed. Upper Saddle River, NJ: Pearson.

Lichtman, M. 2010. Qualitative Research in Education. A user's Guide. 2nd ed. Thousand Oaks, CA: Sage.

Marashe, J., G. T. Ndamba, and E. Chireshe. 2009. "The Teaching of African Traditional Religion in Primary Schools in Zimbabwe: Challenges and Opportunities." Religious Education 104 (1): 38-50.

Masondo, S. 2011. "African Traditional Religion in the Face of Secularism in South Africa." The Journal of the Helen Suzman Foundation 62: 32-38.

Mawdsley, R. D., J. J. Cumming, and E. De Waal. 2008. "Building a Nation: Religion and Values in the Public Schools of the USA, Australia, and South Africa." Education and the Law 20 (2): 83-106.

Mertler, C. A. 2006. Action Research. Teachers as Researchers in the Classroom. Thousand Oaks, CA: Sage.

Miedema, S., and G. D. Bertram-Troost. 2008. "Democratic Citizenship and Religious Education: Challenges and Perspectives for Schools in the Netherlands." British Journal of Religious Education 30: 123-132.

Mkhatshwa, S. 1998. Opening Address on "Multi-religious Education in South Africa". Problems and Prospects in a Pluralistic Society. Pretoria: Research Institute for Theology and Religion.

Rogers, A. 1993. "The Unsayable, Lacanian Psychoanalysis, and the Art of Narrative Interviewing." In Handbook of Narrative Inquiry: Mapping a Methodology, edited by D. J. Clandinin 2007, 99-119. Thousand Oaks, CA: Sage.

Roux, C. 2006. "Children's Spirituality in Social Context: A South African Example.” International Journal of Children's Spirituality 11 (1): 151-163.

Sasson, U., and A. Sasson. 2009. "Religious Education and Community Involvement among Jewish Adolescents." Religious Education 104 (1): 51-63.

Sharma-Brymer, V., and C. Fox. 2008. "Being an Educated Woman in India: A Phenomenological Approach to Narratives." Compare 38 (3): 321-333.

Smock, D. 2005. Teaching about the Religious Other. United States Institute of Peace. Special Report 143. www.usip.org.

Ter Avest, I., and C. Bakker. 2005. "Religion: Voice of the Multi-voiced Self-evaluating the Diversity of Religious and Non-religious Philosophies of Life as part of the Multi-voiced Self." Scriptura 89: 283-292.

Van der Walt, J. L. 2010. "Religion in Education: Is there yet Another Solution?" Koers 75 (1): 79-98. 


\section{Legislation}

DoE (Department of Education). 2003. National Policy on Religion and Education. Pretoria: Government Printer.

DoE (Department of Education). 2001. Manifesto on Values, Education and Democracy. Pretoria: Government Printer.

Republic of South Africa. 1996. The Constitution of the Republic of South Africa (Act 108 of 1996). Pretoria: Government Printer.

Republic of South Africa. 1996. South African Schools Act (Act 84 of 1996). Pretoria: Government Printer.

\section{Court cases}

Christian Education SA v Ministry of Education. 2000 (4) SA 757 (CC); 2000 (10) BCLR 1051 (CESA).

Mfolo and others V Minister of Education, Bophuthatswana. 1994 (1) BCLR 136 (B). 